\title{
A PRIORI SPATIAL SEGMENTATION OF COMMERCIAL PROPERTY MARKET USING HEDONIC PRICE MODELLING
}

\author{
Hamza Usman \\ Universiti Tun Hussein Onn Malaysia; \\ Abubakar Tafawa Balewa University Bauchi, Nigeria \\ e-mail:hamzeeusm@gmail.com \\ Mohd Lizam \\ Faculty of Technology Management and Business, \\ Universiti Tun Hussein Onn Malaysia \\ e-mail:lizam@uthm.edu.my \\ Burhaida Burhan \\ Faculty of Technology Management and Business, \\ Universiti Tun Hussein Onn Malaysia \\ e-mail:burhaida@uthm.edu.my
}

\begin{abstract}
The improvement of property price modelling accuracy using property market segmentation approaches is well documented in the housing market. However, that cannot be said of the commercial property market which is adjudged to be volatile, heterogeneous and thinly traded. This study, therefore, determines if the commercial property market in Malaysia is spatially segmented into submarkets and whether accounting for the submarkets improves the accuracy of price modelling. Using a 11,460 shop-offices transaction dataset, the commercial property submarkets are delineated by using submarket binary dummies in the market-wide model and estimating a separate hedonic model for each submarket. The former method improves the model fit and reduces error by $5.6 \%$ and $6.5 \%$ respectively. The commercial property submarkets are better delineated by estimating a separate hedonic model for each submarket as it improves the model fit by about $7 \%$ and reduces models' error by more than $10 \%$. This study concludes that the Malaysian commercial property market is spatially segmented into submarkets. Modelling the submarkets improves the accuracy and correctness of price modelling.
\end{abstract}

Keywords: market segmentation, hedonic price modelling, submarket, commercial property.

JEL Classification: $D 49, R 30$.

Citation: Usman, H., Lizam, M. \& Burhan, B. (2021). A priori spatial segmentation of commercial property market using hedonic price modelling. Real Estate Management and Valuation, 29(2), 16-28.

DOI: https://doi.org/10.2478/remav-2021-0010

\section{Introduction}

The use of hedonic price modelling in property market valuation, analysis, forecasting and market segmentation abound in literature (Beenstock et al., 2020; Clapp \& Wang 2006; Lisi, 2019; Mora-Garcia et al., 2019; Morano et al., 2019; Usman, at al., 2020a; Zhang et al., 2020). The method is used to capture the implicit prices of property attributes, the effect of location, as well as the price premium and discounts of various property externalities (Kauko, 2003; Michaels \& Smith, 1990; Seo et al., 2019; 
Usman et al., 2020b; Xu et al., 2016). The use of Hedonic Price Model (HPM) is based on the fact that property is considered as a composite good made up of bundles of different constituent parts, so that price is the summation of the implicit prices of the constituent parts (Rosen, 1974). The property constituent parts are the physical characteristics, neighbourhood attributes and locational factors (Gnagey \& Tans, 2018; Usman et al., 2020c; Yuan et al. 2020). Originally, the HPM is based on "one price for all" and assumes equilibrium implicit prices across the whole market (Costa et al., 2016; Lipscomb \& Farmer, 2005). This assumption does not always hold in the property market due to the complexity and heterogeneity of the market as well as other market disruptions (Alas, 2020; Fuerst \& Marcato, 2010; Palm, 1978).

The equilibrium condition of the property market is affected by the location and spatial effects. These spatial effects are the spatial dependence and heterogeneity present at the local and global level respectively (Alas, 2020; Yuan et al., 2020). The failure of the conventional HPM to capture spatial effects in modelling property price leads to spatial autocorrelation, which results in bias and inconsistent estimates (Clapp \& Wang, 2006; Goodman \& Thibodeau, 2003; Leishman et al., 2013; Manganelli et al., 2014). The property spatial effects are attributed to the property submarket effect (Keskin \& Watkins, 2017; Yuan et al., 2020). Each submarket has a distinct equilibrium as well as different demand and supply conditions. Therefore, accounting for and delineating property submarkets would enhance the accuracy and reliability of HPM estimates (Alas, 2020; Goodman \& Thibodeau, 2003; Keskin \& Watkins, 2017; Yuan et al., 2020).

Several attempts have been made to the model property market by accounting for submarket effects using various methods as far back as 1975 until this date (Alas, 2020; Bourassa et al., 2003; Clapp \& Wang, 2006; Goodman \& Thibodeau, 1998; Palm, 1978; Straszheim, 1975). However, most of the studies primarily considered the housing market, neglecting the equally important commercial property market. Fewer studies considered commercial property segmentation, with the majority of them involving the office subsector (Costa \& Cazassa, 2018; Costa et al., 2016; Dunse et al., 2001; Nappi-Choulet, 2009; Sivitanidou, 1995). Few exceptions are hotel properties (Beracha et al., 2018; Kim, 2020), retail properties (Hardin \& Carr, 2006; Sevtsuk \& Kalvo, 2018) and industrial properties (Grissom et al., 1987).

Commercial properties play a strategic role in the economic development of countries and, therefore, require accurate price modelling (Jeong \& Kim, 2011; Raposo \& Evangelista, 2017; Usman \& Lizam, 2020). The accurate pricing of commercial property is affected by its characteristics. The market is imperfect; its assets are heterogeneous, rarely traded and have a high cost of transaction (Hardin III et al., 2017; Wiley, 2017). These characteristics affect the market equilibrium condition as a result of submarket effects (Hardin III \& Carr, 2006). To have accurate estimates, the submarkets are required to be delineated (Alas, 2020; Dunse et al., 2001; Seo, 2016). Malaysia, with an emerging commercial property market (Ling et al., 2017), is lacking empirical studies that delineate the commercial property market to decipher its structure and dynamics. Therefore, the aim of this study is to delineate Malaysia's commercial property market into distinct homogenous submarkets to improve the accuracy of commercial property price modelling. The rest of the paper is structured into a review of related literature followed by methods employed and then a discussion of the empirical result of the study which leads to the conclusions in the last section of the paper. .

\section{Literature Review}

The urban property market is believed to be characterized by price variation. This variation may result from spatial, racial, income, social, demographical, and physical heterogeneities, makingthe property market a composite of separate and compartmentalised submarkets (Soguel et al., 2008; Straszheim, 1975). The market, therefore, requires segmentation. Property market segmentation is the delineation of the property market into distinct submarkets that are homogeneous within themselves and different from others. The property attributes are substitutable within a submarket (Inoue et al., 2020; Pryce, 2013). Property market segmentation has been shown by past literature to have improved the accuracy of property price modelling (Alas, 2020; Bourassa et al., 2007). Numerous methods are used to delineate the property market into distinct submarkets. Although there is a consensus on the improvement of property price prediction from market segmentation, there is no generally accepted method that is considered superior to others to date(Alas, 2020; Bourassa et al., 2007; Keskin \& Watkins, 2017; Yuan et al., 2020). The property market is segmented through the use of a priori criteria 
or the use of data to statistically derive the submarket.

The earliest studies on property market segmentation used the a priori means of delineating submarkets. For instance, Straszheim (1975) used racial differences to delineate property submarkets. Schnare and Struyk (1976) later used the ad hoc method to segment the property market spatially and structurally into submarkets. Using data from Boston, United States, they found mild evidence of market segmentation. Similarly, Palm (1978) delineated the housing market based the real estate boards jurisdiction and the racial-ethnic composition of the neighbourhood. Other studies segmented the housing markets into submarkets based on socio-economic characteristics (Farber, 1986), neighbourhood quality (Keskin, 2008), political districts, wards, stations (Inoue et al., 2018; Ling \& Hui, 2013), quality of public education, census tract and zip code districts (Goodman \& Thibodeau, 1998, 2003), property type (Watkins, 1999; Wolverton et al., 1999), historic district designation (Warren et al., 2017), and land-use zoning regulation (Levkovich et al., 2018). Costa et al. (2016) evaluated the nexus between physical characteristics, spatial submarkets and economic change across different property-type segments of the office market. They found distinct office submarkets. Similarly, Hardin III and Carr (2006) found spatial segmentation among retail centers. Spatial delineation of submarkets was also carried out by Roubi, Ghazaly (2007) in Cairo neighborhoods. Using the Chow F test, they found that parameters are not stable across the neighborhoods. The study was, however, using rental value. A related study using sales values in Cardiff, UK, by Xiao et al. (2016) found evidence of spatial segmentation by street segments and structural segmentation based on building-type. The study concluded that street segments and prior knowledge can serve as the basis for the efficient segmentation of the property market.

Alternatively, property submarkets are derived statistically using data instead of arbitrary imposition. One of the earliest studies that used data-driven methodology for property market segmentation is Dale-Johnson (1982). He used factor analysis to delineate the property market into 13 distinct submarkets. The existence of market segmentation was confirmed using the Chow $\mathrm{F}$ test. Similarly, Watkins (1999) identified structurally differentiated market segments using Principal Component Analysis (PCA). The studyidentified the existence of submarkets using the Chow test conducted on the separate estimated hedonic equations as well as a comparison of the weighted standard error with the standard error of the aggregated model. Other studies used cluster analysis or combination of factor and cluster analysis to derive property submarkets. For instance, Burhan (2014) combined PCA and cluster analysis to derive housing submarkets in Johor, Malaysia. With the aid of Geographical Information System, Burhan found that housing market dynamics are best captured by the combined structural and spatial housing attributes effects. The work of Shi et al. (2015) combined cluster analysis using Fuzzy C-Mean (FCM) in what they called "innovative" clustering as well as the Adaptive Neural Fuzzy Inference System (ANFIS) to delineate property markets, reportingimproved prediction accuracy. Gabrielli et al. (2017) also combined cluster analysis with fuzzy analysis to derive housing submarkets. The combined approaches show that the property market is segmented with gaps and overlaps among the submarkets.

Other methods of deriving submarkets using data include generalised fused LASSO (Inoue et al., 2018), fused minimax concave penalty (fused-MCP) (Inoue et al., 2020), multilevel models (Leishman et al., 2013), the Artificial Neural Network (Kauko et al., 2002), and a number of spatial models (Chegut et al., 2020). Zhuo Chen et al. (2009) compared property market segmentation using alternative methods - statistical and a priori methods. Seven procedures were used for submarket derivation. Two from statistical cluster analysis, a priori segmentation based on 3 classifications, a hybrid of a cluster and local government jurisdiction, and, finally, an arbitrary $4 \mathrm{X} 4$ mile grid of the property market. The study found that the a priori determined submarkets from local government jurisdictions, school districts and expert opinions performed better than the statistically driven submarkets. The performance of a priori classification is also confirmed by Bourassa et al. (2007). They compared the conventional hedonic a priori models with spatial statistical methods using property sales data from New Zealand. They found that the a priori defined expert boundaries model performed better than the spatial statistical models without the inclusion of submarket dummies. However, most of these studies are on the housing market which may not be generalizable to commercial properties. This research, therefore, aims to test the efficacy of spatial a priori segmentation in delineating commercial property markets into submarkets.

\section{Data and Methods}


The commercial property transaction data was obtained from the National Property Information Centre (NAPIC) in Malaysia. The NAPIC is a government agency under Malaysia's ministry of finance. The agency keeps a record of property transaction information for stamp duty purposes. The data contained information on Kuala-Lumpur and Selangor State in Malaysia, which are the administrative and commercial hub of the country. The commercial property market in Malaysia comprises office buildings, retail buildings and a hybrid of office-shop and specific purpose officeretail buildings. The office buildings, retail complexes and office retail buildings are complex developments which are rarely and thinly traded. The office-buildings are small-scale offices and retail buildings which are transacted regularly. The study is limited to shop-office buildings of the commercial property market due to the availability of such data in Malaysia. The obtained data have valid entries for the following districts - Gombak, Hulu Langat, Hulu Selangor, Kelang, Kuala Langat, Kuala Lumpur, Petaling, Sepang and Putra Jaya, which are assumed as potential submarkets. The data set contains information on variables such as plot area, building area, date of transaction and date of construction, based on which the age of the properties are determined, building height, level of transactions. The variables used in the empirical model are defined in Table 1.

Table 1

Variables definition

\begin{tabular}{|c|c|c|}
\hline & Definition & Measurement \\
\hline Ln_Price & Logarithm of sales prices & $\begin{array}{l}\text { Dependent, } \\
\text { Continuous }\end{array}$ \\
\hline ln_plota & $\begin{array}{l}\text { Logarithm of plot area. This is the total area of a plot on which } \\
\text { the subject building is situated. It is measured in square metres }\end{array}$ & Continuous \\
\hline ln_blda & $\begin{array}{l}\text { Logarithm of building area. This is the total area of built floor } \\
\text { area. It is measured in square metres }\end{array}$ & Continuous \\
\hline ln_agen_1 & $\begin{array}{l}\text { Logarithm of building age. Buidling age is the difference } \\
\text { between the dates of sales and construction }\end{array}$ & Continuous \\
\hline age_dummy & The dummy of age. New buildings are coded 1 , otherwise 0. & Dummy \\
\hline h_low & $\begin{array}{l}\text { Low height. Low height is defined as buildings with } 2 \text { levels } \\
\text { (stories) which are coded } 1 \text {, otherwise } 0 \text {. }\end{array}$ & Dummy \\
\hline h_med & $\begin{array}{l}\text { Medium height. Medium height is defined as buildings with } 2-4 \\
\text { levels which are coded } 1 \text {, otherwise } 0 \text {. }\end{array}$ & Dummy \\
\hline h_high & $\begin{array}{l}\text { High height. High height is defined as buildings with } 5 \text { levels } \\
\text { and above which are coded } 1 \text {, otherwise } 0 \text {. }\end{array}$ & Dummy \\
\hline bldg_unit & $\begin{array}{l}\text { If the whole building is sold its coded } 1 \text { whereas if only a unit in } \\
\text { the building is sold, it is coded } 0 \text {. }\end{array}$ & Dummy \\
\hline ground_flo & $\begin{array}{l}\text { If the level of transaction is at ground floor it is coded } 1 \text {, } \\
\text { otherwise } 0\end{array}$ & Dummy \\
\hline upper_medi & $\begin{array}{l}\text { Upper-medium floors. Transactions between } 2^{\text {nd }} \text { and } 4^{\text {th }} \text { floors } \\
\text { are coded } 1 \text {, otherwise } 0\end{array}$ & Dummy \\
\hline upper_high & $\begin{array}{l}\text { Upper-high. Transactions between the fifth level and above are } \\
\text { coded } 1 \text { otherwise } 0 \text {. }\end{array}$ & Dummy \\
\hline ln_d_klcc & $\begin{array}{l}\text { Logarithm of distance to the center of Kuala Lumpur. This is } \\
\text { taken as the overall CBD }\end{array}$ & Continuous \\
\hline ln_d_cty_cc & Logarithm of distance to the nearest city center & Continuous \\
\hline ln_d_tstations & Logarithm of the distance to the nearest train station & Continuous \\
\hline Locat. dummies & Transactions in a particular district is coded 1 otherwise 0 & Dummy \\
\hline Time dummies & Years of transactions are accounted for by dummy entries & Dummy \\
\hline
\end{tabular}

Source: own study.

The data were screened for missing values, wrong entries, normality, linearity and homoscedasticity, resulting in 11,460 observations retained for the empirical market segmentation analysis. The empirical analysis is structured into a market-wide (aggregated) model, aggregated model with submarket dummies, and a separate hedonic equation for each submarket. The market- 
wide model is estimated using Ordinary Least Squares (OLS) regression. A log-log linear model is employed. The log-log linear model allows for a logarithmic transformation of both sides of the equation, and the use of a dummy variable was shown to be more efficient than linear specification (Soguel et al., 2008). The market-wide model is estimated using equation 1 below.

$$
\ln P_{i}=\beta_{i}+\sum_{k} \beta_{k i} \ln X_{k i}+\sum_{l} \beta_{l i} d X_{l i}+\sum_{n} \beta_{n i} T d_{n i}+\varepsilon
$$

Where $\ln P_{i}$ is the $n \times 1$ vector of commercial property prices, $\beta_{k i}, \beta_{l i}, \beta_{n i}$ are regression coefficients of logarithmically transformed continuous commercial property attributes, dummy commercial property attributes and time dummies, and $\ln X_{k i}, d X_{l i}$, and $T d_{n i}$ are $i \times k, i \times l$ and $i \times n$ vectors logarithmically transformed continuous commercial property attributes, dummy commercial property attributes and time dummies respectively, where $i$ is the number of observations and $\boldsymbol{\varepsilon}$ is the error term which is assumed to be identically and independently distributed (i.i.d.).

The submarket effect is controlled by binary dummy variables representing the commercial property submarkets. This approach, according to Lisi (2019), is a simpler methodology to implement. The model is specified in Equation 2.

$$
\ln P_{i}=\beta_{i}+\sum_{k} \beta_{k i} \ln X_{k i}+\sum_{l} \beta_{l i} d X_{l i}+\sum_{n} \beta_{n i} T d_{n i}+\sum_{j} \beta_{j i} J d+\varepsilon
$$

Where $J d$ represents commercial property submarket dummies. Alternatively, the submarkets are delineated by using a separate hedonic equation for each submarket, which is considered as a useful methodology for delineating spatial submarkets (Yuan et al., 2020). The submarkets are modelled as specified in Equation 3.

$$
\ln P_{i j}=\beta_{i j}+\sum_{k j} \beta_{k i j} \ln X_{k i j}+\sum_{l j} \beta_{l i j} d X_{l i j}+\sum_{n j} \beta_{n i j} T d_{n i j}+\varepsilon
$$

Where $\ln P_{i j}$ is the price of commercial property $i$ in commercial property submarket $j$. For other property attributes and parameters, $i$ is associated with particular commercial property observations in a submarket $j$.

The presence of a commercial property submarket is evaluated using two recommended methods - Chow F test and the model's weighted errors (Dale-Johnson, 1982; Schnare \& Struyk, 1976; Xiao et al., 2016). The Chow test tests the hypotheses of model equality across the submarket. The Chow test is estimated as presented in Equation 4.

$$
F=\frac{\left[S S R_{c}-\left(S S R_{1}+S S R_{2}\right)\right]}{\left(S S R_{1}+S S R_{2}\right)} X \frac{\left(N_{1}+N_{2}-2 k\right)}{k}
$$

Where, $\mathrm{SSR}_{\mathrm{c}}, \mathrm{SSR}_{1}$, and $\mathrm{SSR}_{2}$ represent the sum of squared residuals for the aggregate model and individual models respectively. $\mathrm{N}_{1}$ and $\mathrm{N}_{2}$ represent the number of observations in respective models. The performance of the separate submarkets model is evaluated using weighted root mean squared error (RMSE). It is calculated as presented in Equation 4.

$$
R M S E w=\frac{N_{1}+K_{1}-1}{\sum\left(N_{j}+K_{j}-1\right)}(R M S E 1)+\frac{N_{2}+K_{2}-1}{\sum\left(N_{j}+K_{j}-1\right)}(R M S E 2)+\cdots+\frac{N_{j}+K_{j}-1}{\sum\left(N_{j}+K_{j}-1\right)}(R M S E j)
$$

Where $\mathrm{N}_{j}$ is the number of observations in a $j$ th submarket; and there are $j$ submarkets.

\section{Empirical Results}

The empirical result is based on the two methods used in delineating the commercial property submarkets. The first method controls for the effect of the submarkets in a market-wide model, whereas the second method estimates a separate hedonic equation for each submarket. The result of the market-wide model and submarket controlled model is presented in Table 1 as model (1) and model (2) respectively. Two variables, dummy of high height and year 2001, were affected by multicollinearity and thus removed from the equation. All the parameters have a significant coefficient with expected signs except the age and year 2000 dummies. The empirical result indicated that the market-wide hedonic model explained about 62.8 per cent $\left(R^{2}=0.628\right)$ of the commercial property price variance. The model has a Root Mean Squared Error (0.54933), Akaike Information Criterion (AIC) and Bayesian Information Criterion (BIC) of 18818.6 and 19016.9 respectively. The model shows significant heteroscedasticity as indicated in the Breusch-Pagan test value of 23.53, which is significant at a 0.001 significance level. The presence of heteroscedasticity indicates the existence of autocorrelation in the model and the potential of submarket existence (Islam \& Asami, 2010; Soguel et al., 2008). 
Table 2

Result of OLS Hedonic Regression Models

\begin{tabular}{|c|c|c|}
\hline & $(1)$ & $(2)$ \\
\hline & ln_price & ln_price \\
\hline ln_plota & $0.0859^{* * *}$ & $0.0908^{* * *}$ \\
\hline ln_blda & $0.803^{* * *}$ & $0.773^{\text {*** }}$ \\
\hline ln_agen_1 & $-0.102^{* * *}$ & $-0.113^{* * *}$ \\
\hline age_dummy & -0.0179 & -0.00141 \\
\hline h_low & $-0.409^{\star \star *}$ & $-0.252^{* * *}$ \\
\hline h_med & $-0.318^{* * *}$ & $-0.218^{* * *}$ \\
\hline h_high & 0 & 0 \\
\hline bldg_unit & $-0.185^{* * *}$ & $-0.194^{* * *}$ \\
\hline ground_flo & $0.172^{* * *}$ & $0.145^{\text {*** }}$ \\
\hline upper_medi & $-0.471^{* * *}$ & $-0.519^{* * *}$ \\
\hline upper_high & $-0.349^{* * *}$ & $-0.388^{* * *}$ \\
\hline ln_d_klcc & $-0.140^{\star * *}$ & $-0.151^{* * *}$ \\
\hline ln_d_cty_cc & $-0.0868^{* * *}$ & $-0.137^{* * *}$ \\
\hline ln_d_tstations & $-0.0808^{* * *}$ & $-0.0452^{* * *}$ \\
\hline by2000 & $-0.282^{* * *}$ & $-0.363^{* * *}$ \\
\hline y2000 & -0.104 & $-0.160^{*}$ \\
\hline $\mathrm{y} 2001$ & 0 & 0 \\
\hline $\mathrm{y} 2002$ & $-0.240^{* * *}$ & $-0.273^{* * *}$ \\
\hline $\mathrm{y} 2003$ & 0.00473 & -0.0610 \\
\hline y2004 & 0.0591 & -0.00337 \\
\hline y2005 & 0.0644 & 0.00764 \\
\hline y2006 & $0.120^{*}$ & 0.0591 \\
\hline y2007 & $0.235^{\star \star *}$ & $0.165^{\star *}$ \\
\hline $\mathrm{y} 2008$ & $0.237^{\star * *}$ & $0.211^{* * *}$ \\
\hline y2009 & $0.257^{\star * *}$ & $0.239^{* * *}$ \\
\hline $\mathrm{y} 2010$ & $0.292^{* * *}$ & $0.282^{\star \star *}$ \\
\hline $\mathrm{y} 2011$ & $0.602^{* * *}$ & $0.565^{* * *}$ \\
\hline y2012 & $0.699^{* * *}$ & $0.656^{* * *}$ \\
\hline gomak & & $-0.698^{* * *}$ \\
\hline hulu_langa & & $-0.834^{\text {** }}$ \\
\hline hulu_selan & & $-0.963^{\text {*** }}$ \\
\hline kelang & & $-0.650^{* * *}$ \\
\hline kuala_lang & & $-0.806^{\text {*** }}$ \\
\hline kuala_lump & & $-0.454^{\text {*** }}$ \\
\hline petaling & & $-0.386^{* *}$ \\
\hline sepang & & $-0.907^{* * *}$ \\
\hline putra_jaya & & 0 \\
\hline _cons & $11.41^{\text {*** }}$ & $12.34^{* * *}$ \\
\hline$N$ & 11460 & 11460 \\
\hline$R^{2}$ & 0.628 & 0.663 \\
\hline adj. $R^{2}$ & 0.627 & 0.662 \\
\hline$A I C$ & 18818.6 & 17705.3 \\
\hline$B I C$ & 19016.9 & 17962.5 \\
\hline RMSE & 0.55933 & 0.5231 \\
\hline Breusch-Pagan & $23.53^{* * *}$ & 0.80 \\
\hline
\end{tabular}

Source: own study. 
Model 2 used the binary dummies to account for the submarkets in the market-wide model. Gombak, Hulu Langat, Hulu Selangor, Kelang, Kuala Langat, Kuala Lumpur, Petaling, Sepang, and Putra Jaya submarkets were controlled. However, the coefficient of the Putra Jaya submarket dummy was omitted due to collinearity. Accounting for the effect of submarkets improved Model 2 variance explanation from 62.8 per cent $\left(R^{2}=0.628\right)$ to 66.3 per cent $\left(R^{2}=0.663\right)$, making for a $5.6 \%$ improvement in model fit. Similarly, both AIC and BIC are decreased from 18,818.6 and 19,016.9 to 17,705 and $17,962.5$, indicating a $5.9 \%$ and $5.6 \%$ reduction in models' information lost respectively. The model's RMSE equally reduced from 0.55933 to 0.5231 , indicating a $6.5 \%$ improvement in model accuracy. According to Schnare and Struyk (1976), submarket delineation should be considered if the reduction of the submarket's model error from the market wide-model reaches $10 \%$. However, Dale-Johnson (1982) recommended a 5\% reduction of the model error. Accordingly, delineating a submarket by accounting for the submarket dummies reduces the market-wide hedonic model RMSE by $6.5 \%$ above the value recommended by Dale-Johnson (1982). Similarly, imposing a submarket eliminates heteroscedasticity in the submarket model as indicated by the Breusch-Pagan test value of 0.80 , which is statistically not significant. This result confirms the claim made by Lisi (2019) that the submarket effect can be modelled using simple binary dummies, which also improves the accuracy and correctness of the model (Bourassa et al., 2007).

Alternatively, the submarkets are delineated by estimating separate hedonic models for each submarket. Firstly, 9 models were estimated for Gombak, Hulu Langat, Hulu Selangor, Kelang, Kuala Langat, Kuala Lumpur, Petaling, Sepang, and Putra Jaya submarkets respectively. A series of Chow F tests were conducted to test the hypothesis of coefficient equality. Result of the first Chow Test shows that separating Hulu Langat and Kuala Langat does not improve fit. Sepang and Putra Jaya have nonsignificant Chow F statistics with most of the other districts. However, the Lowest Chow F statistics would be considered. Hulu Langat, Kuala Langat, and Sepang are Contagious Districts and all have insignificant Chow F Statistics. The three districts models are therefore aggregated. Putra Jaya is closest to Kuala Lumpur and has very insignificant Chow F statistics ( $p$-value $=0.999$ ). Thus, the Kuala Lumpur and Putra Jaya models are aggregated. Accordingly, six submarkets were delineated as presented in Table 3.

Table 3 shows the 6 delineated submarkets. They are Gombak, Kuala Langat and Sepang, Hulu Selangor, Kelang, Kuala Lumpur and Petaling Submarket.

Table 3

Submarket Models

\begin{tabular}{|c|c|c|c|c|c|c|}
\hline & (3) & (4) & (5) & (6) & (7) & $(8)$ \\
\hline & ln_price & ln_price & ln_price & ln_price & ln_price & ln_price \\
\hline ln_plota & $0.157^{* *}$ & $0.115^{\star * * *}$ & 0.444 & $0.108^{* *}$ & 0.0387 & $0.118^{* \star *}$ \\
\hline $\ln \_$blda & $0.756^{\text {*** }}$ & $0.782^{* * *}$ & $1.050^{* * *}$ & $0.838^{\star * \star}$ & $0.851^{\text {*** }}$ & $0.691^{* * *}$ \\
\hline ln_agen_1 & $-0.0968^{* * *}$ & $-0.143^{* * *}$ & 0.0912 & $-0.124^{* * *}$ & $-0.136^{* * *}$ & $-0.0764^{* * *}$ \\
\hline age_dum & $-0.150^{*}$ & 0.0562 & -0.164 & 0.0627 & -0.0517 & 0.0244 \\
\hline h_low & 0 & 0 & -0.177 & 0 & -0.0539 & 0 \\
\hline h_med & $0.0891^{*}$ & 0.0324 & 0 & $0.134^{* * *}$ & $-0.145^{* * *}$ & $0.104^{* * *}$ \\
\hline h_high & -0.00870 & $0.199^{* * \star}$ & -0.470 & -0.0437 & 0 & $0.342^{* * *}$ \\
\hline bldg_unit & -0.0693 & $-0.115^{* *}$ & -0.165 & 0.682 & $-0.497^{\star * *}$ & $-0.202^{* * *}$ \\
\hline ground_flo & $0.405^{* *}$ & 0.00601 & -0.0223 & $1.215^{* *}$ & 0 & $0.157^{*}$ \\
\hline upper_med & $-0.540^{* * *}$ & $-0.636^{* * *}$ & 0 & 0.505 & $-0.640^{* * *}$ & $-0.570^{* * *}$ \\
\hline upper_high & -0.264 & -0.329 & 0 & 0 & $-0.495^{* * *}$ & $-0.606^{* * *}$ \\
\hline ln_d_klcc & $-0.348^{* k+k}$ & $-0.309^{* * *}$ & 0.727 & $-0.124^{*}$ & $-0.122^{* * *}$ & -0.00435 \\
\hline ln_d_cty_cc & $-0.0739^{* *}$ & $-0.0532^{* * *}$ & -0.324 & -0.0385 & $-0.254^{* * *}$ & $-0.219^{* * *}$ \\
\hline ln_d_tstation & $-0.107^{* * *}$ & $0.0370^{* *}$ & 0.0620 & $0.0805^{* *}$ & -0.0161 & $-0.153^{\text {*** }}$ \\
\hline bf2000 & 0.197 & $-0.424^{* * *}$ & 0.569 & -0.108 & $-0.326^{*}$ & 0.0555 \\
\hline y2000 & 0 & -0.126 & 0.685 & 0 & 0 & 0 \\
\hline y2001 & 0.155 & 0 & 0 & 0.0321 & $0.410^{*}$ & 0.0439 \\
\hline y2002 & 0.0679 & $-0.549^{* * *}$ & 0.786 & -0.0587 & 0.0752 & 0.197 \\
\hline y2003 & 0.270 & 0.0297 & 0 & 0.0659 & -0.0335 & 0.174 \\
\hline y2004 & 0.188 & 0.0803 & 0.384 & 0.101 & 0.183 & 0.173 \\
\hline
\end{tabular}




\begin{tabular}{|c|c|c|c|c|c|c|}
\hline y2005 & 0.316 & 0.110 & 0.273 & 0.145 & 0.199 & 0.171 \\
\hline y2006 & 0.274 & 0.0775 & 0.514 & 0.109 & $0.365^{\star \star}$ & 0.185 \\
\hline y2007 & 0.424 & $0.174^{*}$ & 0.269 & $0.232^{*}$ & $0.470^{\star * *}$ & $0.323^{*}$ \\
\hline y2008 & $0.454^{*}$ & $0.280^{* * *}$ & 0 & 0 & 0 & $0.352^{* *}$ \\
\hline y2009 & 0.398 & $0.266^{* \star *}$ & 0 & 0 & 0 & $0.467^{k * *}$ \\
\hline y2010 & $0.547^{*}$ & $0.263^{\text {*** }}$ & 0 & 0 & 0 & $0.462^{* * \star}$ \\
\hline y2011 & $0.751^{* * *}$ & $0.579^{* * *}$ & 0 & 0 & 0 & $0.781^{* * *}$ \\
\hline y2012 & $0.825^{* * *}$ & $0.593^{\text {*** }}$ & 0 & 0 & 0 & $0.920^{\star * *}$ \\
\hline _cons & $12.68^{* \star * *}$ & $11.20^{* \star *}$ & -0.704 & $7.758^{\star \star \star}$ & $12.28^{* \star *}$ & $11.81^{* * *}$ \\
\hline$N$ & 1004 & 2936 & 66 & 889 & 3021 & 3544 \\
\hline$R^{2}$ & 0.694 & 0.702 & 0.807 & 0.708 & 0.686 & 0.618 \\
\hline $\operatorname{adj} \cdot R^{2}$ & 0.686 & 0.700 & 0.733 & 0.701 & 0.684 & 0.615 \\
\hline AIC & 1390.6 & 3427.1 & 67.24 & 746.2 & 5047.7 & 5807.1 \\
\hline BIC & 1523.2 & 3588.7 & 108.8 & 846.8 & 5174.0 & 5973.8 \\
\hline RMSE & 0.47726 & 0.43177 & 0.35784 & 0.36388 & 0.55601 & 0.54692 \\
\hline B-P Test ${ }^{+}$ & $13.07^{* *}$ & 0.26 & 0.08 & 0.47 & $15.45^{\star \star *}$ & $3.12(0.07)$ \\
\hline
\end{tabular}

$t$ statistics in parentheses

${ }^{*} p<0.05,{ }^{* *} p<0.01,{ }^{* * *} p<0.001$; Model 1 = Aggregated Market; Model 2 = Gombak; Model 3 = Hulu Langat, Kuala Langat, Sepang; Model $4=$ Hulu Selangor; Model 5 = Kelang; Model 6 = Kuala Lumpur; Model 7 = Petaling

Source: own study.

The result shows that the Gombak, Kuala Langat and Sepang, Hulu Selangor, Kelang, Kuala Lumpur and Petaling submarket models produced $\mathrm{R}^{2}$ values of $0.694,0.702,0.807,0.708,0.686$, and 0.618 , an improvement of about $10.5 \%, 11.8 \%, 28.5 \%, 12.7 \%, 9.2 \%$ and $-1.6 \%$ respectively over the market-wide model. The weighted improvement of $\mathrm{R}^{2}$ shows about $7 \%$. Similarly, the submarket models show a significant reduction in the Root Mean Squared Errors (RMSE) compared to the market-wide model. The 6 submarket models have a weighted RMSE of 0.4989 , a $10.8 \%$ reduction in models' errors over the market-wide model. This shows the improved accuracy and correctness of the submarkets delineated using separate model's equations and satisfied the recommended threshold for submarket existence (Dale-Johnson, 1982; Schnare \& Struyk, 1976; Xiao et al., 2016). Similarly, the AIC and BIC statistics are significantly reduced for all the six submarket indicating reduced models' information loss. The presence of heteroscedasticity in the market-wide model is significantly reduced in the submarket models. Only two of the six submarket models have issues with heteroscedasticity. This confirms the submission that accounting for submarkets reduces heteroscedasticity (Islam \& Asami, 2010; Soguel et al., 2008).

The hypothesis of model equality is tested using the Chow $\mathrm{F}$ test. The Chow test result is presented in Table 4.

Table 4

Chow F Test result

\begin{tabular}{llllll}
\hline \multicolumn{1}{c}{ Gombak } & Gombak & $\begin{array}{c}\text { Hulu Langat, } \\
\text { Kuala Langat, } \\
\text { Sepang }\end{array}$ & $\begin{array}{c}\text { Hulu } \\
\text { Selangor }\end{array}$ & Kelang & $\begin{array}{c}\text { Kuala } \\
\text { Lumpur }\end{array}$ \\
\hline $\begin{array}{l}\text { Hulu Langat, Kuala } \\
\text { Langat, Sepang }\end{array}$ & $7.946(0.000)$ & & & & \\
\hline Hulu Selangor & $4.562(0.000)$ & $1.985(0.002)$ & & & \\
\hline Kelang & $374.8(0.000)$ & $9.871(0.000)$ & $3.487(0.000)$ & & \\
\hline $\begin{array}{l}\text { Kuala Lumpur, Putra } \\
\text { Jaya }\end{array}$ & $6.960(0.000)$ & $20.22(0.000)$ & $2.649(0.000)$ & $9.715(0.000)$ & \\
\hline Petaling & $13.52(0.000)$ & $53.06(0.000)$ & $3.119(0.000)$ & $8.273(0.000)$ & $7.422(0.000)$ \\
\hline$p$ value in parentheses & & & & &
\end{tabular}

Source: own study. 
The Chow test result shows that all the F statistics are very significant. This shows that the six delineated commercial property submarkets are distinct from one another and shows that the commercial property market is spatially non-stationary (Baudry \& Maslianskaia-Pautrel, 2016; Yuan et al., 2020). This result shows that estimating a separate hedonic equation for each submarket is an effective means of delineating submarkets.

The performance of submarket delineations methods - using submarket dummies and separate hedonic equation for each submarket - used in this study are evaluated using the relative improvement of model accuracy attributed to each method. Weighted percentage improvement in $\mathrm{R}^{2}$ and RMSE are used to compare the performance of the models as presented in Table 5.

Table 5

Model Performance Evaluation

\begin{tabular}{lccc}
\hline Measures & Market-wide model & Submarket dummies & Submarket equations \\
\hline $\mathbf{R}^{2}$ & 0.628 & $0.663(5.6 \%)$ & $0.672(7 \%)$ \\
RMSE & 0.55933 & $0.5231(6.5 \%)$ & $0.49889(10.8 \%)$ \\
\hline
\end{tabular}

$\%$ improvement in parentheses

Source: own study.

The result in Table 5 shows that submarket delineation using submarket dummies improved the $\mathrm{R}^{2}$ value by $5.6 \%$ and reduced the error by $6.5 \%$, whereas delineation using a separate hedonic equation for submarkets improved $\mathrm{R}^{2}$ by $7 \%$ and reduced the error by $10.8 \%$. The measures in separate submarket hedonic model methods are based on a weighted average (Schnare \& Struyk, 1976; Xiao et al., 2016). Although the two methods meet the requirement for establishing submarkets based on the recommendation of Dale-Johnson (1982) that the reduction in error as a result of segmentation should be greater than $5 \%$, the use of separate hedonic models for a distinct submarket was found to perform better than just controlling the effect of submarkets using binary dummies. The advantage of using submarket dummies is its simplicity of application and ease of interpretation (Lisi, 2019). The method was also found to perform credibly well in other studies (Bourassa et al., 2007).

\section{Conclusion}

Property market segmentation is an important tool for pricing, investment, urban planning, property tax assessment, and mortgages. Several decades of research in property market segmentation hav revealed improved property pricing accuracy as a result of segmentation. Nevetheless, most studies are devoted to the housing market with fewer studies in the commercial property market. Similarly to the housing market, the commercial property market is also complex, heterogeneous and, more importantly, thinly traded; as such, it cannot be adequately modelled by a simple unitary equilibrium model (Xiao et al., 2016). Such complexities arise from spatial, structural and other peculiarities that make the market heterogeneous up to a certain scale, such that properties at a submarket level are a homogeneous and close substitute.

The aim of this study, therefore, was to spatially delineate the Malaysian commercial property market into property submarkets that are homogenous within themselves and heterogeneous across others using the Ordinary Least Squares (OLS) hedonic pricing model. The study was limited to shopoffices using rich commercial property transaction data as well as using a priori defined submarkets based on administrative districts in Selangor state and Kuala Lumpur in Malaysia. The study tested a hypothesis of whether commercial properties priced similarly or differently across the market and whether property market segmentation improves the accuracy of commercial property pricing.

The study found that commercial properties are priced differently and are segmented into distinct submarkets. Accounting for the submarket effect in a market-wide model improves model fit and reduces model error. Reduction in model error and improvement in the model is higher in separated models estimated for each submarket. The weighted model fit improves by about $7 \%$ and the error is reduced by more than $10 \%$, thereby confirming model correctness and accuracy improvement, as well as the existence of distinct submarkets. The limitation of this study is that it is limited to only a priori defined submarkets which are imposed rather than modelled. It is recommended that further studies compare the performance of a priori determined submarkets and statistically data-driven submarkets in the commercial property market. 


\section{Acknowledgement:}

The authors would like to thank the Ministry of Education of Malaysia for supporting this research under the Fundamental Research Grant Scheme Vot No. FRGS/1/2018/SS08/UTHM/02/1, partially sponsored by Universiti Tun Hussein Onn Malaysia.

\section{References}

Alas, B. (2020). A multilevel analysis of housing submarkets defined by the municipal boundaries and by the street connections in the metropolitan area: Istanbul. Journal of Housing and the Built Environment 35, 1201-1217. https:// doi.org/10.1007/s10901-020-09735-7

Baudry, M., \& Maslianskaia-Pautrel, M. (2016). Revisiting the hedonic price method in the presence of market segmentation. Environmental Economics and Policy Studies, 18(4), 527-555. https://doi.org/10.1007/s10018-015-0122-5

Beenstock, M., Feldman, D., \& Felsenstein, D. (2020). Identifying local housing markets through revealed preference. Journal of Property Research, 37(2), 118-146. https:// doi.org/10.1080/09599916.2020.1714698

Beracha, E., Hardin, W. G. III, \& Skiba, H. M. (2018). Real Estate market segmentation: Hotels as exemplar. The Journal of Real Estate Finance and Economics, 56, 252-273. https://doi.org/10.1007/s11146-017-9598-z

Bourassa, S. C., Cantoni, E., \& Hoesli, M. (2007). Spatial dependence, housing submarkets, and house price prediction. The Journal of Real Estate Finance and Economics, 35, 143-160. https:// doi.org/10.1007/s11146-007-9036-8

Bourassa, S. C., Hoesli, M., \& Peng, V. S. (2003). Do Housing Submarkets Really Matter? Journal of Housing Economics, 12, 12-28. https://doi.org/10.1016/S1051-1377(03)00003-2

Burhan, B. (2014). Spatial mechanism of hedonic price functions for housing submarket analysis. Saga University, PhD thesis.

Chegut, A. M., Eichholtz, P. M. A., \& Rodrigues, P. J. M. (2015). Spatial dependence in international office markets. The Journal of Real Estate Finance and Economics, 51(2), 317-350. https://doi.org/10.1007/s11146-014-9484-x

Clapp, J. M., \& Wang, Y. (2006). Defining neighborhood boundaries: Are census tracts obsolete? Journal of Urban Economics, 59, 259-284. https://doi.org/10.1016/i.jue.2005.10.003

Copiello, S. (2019, August). 2020, Spatial dependence of housing values in Northeastern Italy. Cities (London, England), 96, 1-10. Https://Doi.Org/10.1016/J.Cities.2019.102444

Costa, O., \& Cazassa, E. (2018). How relevant are generalist real estate indices in emerging markets? Rausp Management Journal, 53(2), 141-151. https://doi.org/10.1016/j.rauspm.2017.06.006

Costa, O., Fuerst, F., \& Mendes-Da-Silva, W. (2016). Office Market Segmentation In Emerging Markets : A Study Of Sao Paulo. Https://Doi.Org/10.13140/Rg.2.2.35578.70083 https://doi.org/10.2139/ssrn.2831615

Dale-Johnson, D. (1982). An alternative approach to housing market segmentation using hedonic price data. Journal of Urban Economics, 11, 311-332. https:// doi.org/10.1016/0094-1190(82)90078-X

Dunse, N., Leishman, C., \& Watkins, C. (2001). Classifying office submarkets. Journal of Property Investment \& Finance, 19(3), 236-250. https:/ / doi.org/10.1108/14635780110387592

Farber, S. (1986). 1986, Market segmentation and the effects on group homes for the handicapped on residential property values. Urban Studies (Edinburgh, Scotland), 23, 519-525. https://doi.org/10.1080/00420988620080801

Fuerst, F., \& Marcato, G. (2010). Re-thinking commercial real estate market segmentation. Working Papers In Real Estate \& Planning 12(10).

Gabrielli, L., Giuffrida, S., \& Trovato, M.R. (2017). Gaps and overlaps of urban housing submarket: hard clustering and fuzzy clustering approaches. In: Stanghellini, S., Morano, P., Bottero, M., \& Oppio, A. (eds). Appraisal: From Theory to Practice. Green Energy and Technology. Springer, Cham. https://doi.org/10.1007/978-3-319-49676-4_15

Gnagey, M., \& Tans, R. (2018). Property price determinants in Indonesia. Bulletin of Indonesian Economic Studies, 54(1), 61-84. https://doi.org/10.1080/00074918.2018.1436158

Goodman, A. C., \& Thibodeau, T. G. (1998). Housing market segmentation. Journal of Housing Economics, 7, 121-143. https://doi.org/10.1006/ihec.1998.0229 
Goodman, A. C., \& Thibodeau, T. G. (2003). Housing market segmentation and hedonic prediction accuracy. Journal of Housing Economics, 12(3), 181-201. https://doi.org/10.1016/S1051$\underline{1377(03) 00031-7}$

Grissom, T. V., Hartzell, D. J., \& Liu, C. H. (1987). An approach to industrial real estate market segmentation and valuation using the arbitrage pricing paradigm. Real Estate Economics, 15(3), 199_ 219. https:// doi.org/10.1111/1540-6229.00428 https:// doi.org/10.1111/1540-6229.00428

Hardin, W., \& Carr, J. (2006). Disaggregating neighborhood and community center property types. Journal of Real Estate Research, 28(2), 167-192. https://doi.org/10.1080/10835547.2006.12091174

Hardin, W. G. III, Jiang, X., \& Wu, Z. (2017). Inflation illusion, expertise and commercial real estate. The Journal of Real Estate Finance and Economics, 55(3), 345-369. https://doi.org/10.1007/s11146-016$\underline{9587-7}$

Inoue, R., Ishiyama, R., \& Sugiura, A. (2018). Identification of geographical segmentation of the rental apartment market in the Tokyo metropolitan area. In 10th International Conference On Geographic Information Science (Gisience 2018) (Pp. 1-6). Germany.

Inoue, R., Ishiyama, R., \& Sugiura, A. 2020, Identifying local differences with fused-mcp: an apartment rental market case study on geographical segmentation detection, Japanese Journal Of Statistics And Data Science. Springer Singapore. https://doi.org/10.1007/S42081-019-00070-Y https://doi.org/10.1007/s42081-019-00070-y

Islam, K. S., \& Asami, Y. (2010). Housing market segmentation: A review. Review of Urban and Regional Development Studies, 21(2), 93-109. https://doi.org/10.1111/J.1467-940x.2009.00161.X

Jeong, S., \& Kim, J. (2011). A study of retail property prices in Seoul. In ERES Conference 2011.

Kauko, T. (2003). Residential property value and locational externalities on the complementarity and substitutability of approaches. Journal of Property Investment \& Finance, 21(3), 250-270. https://doi.org/10.1108/14635780310481676

Kauko, T., Hooimeijer, P., \& Hakfoort, J. (2002). Capturing housing market segmentation: An alternative approach based on neural network modelling. Housing Studies, 17(6), 875-894. https://doi.org/10.1080/02673030215999

Keskin, B. (2008). Hedonic analysis of price in the Istanbul housing market. International Journal of Strategic Property Management, 12(2), 125-138. https://doi.org/10.3846/1648-715X.2008.12.125-138

Keskin, B., \& Watkins, C. (2017). Defining Spatial Housing Submarkets: Exploring The Case For Expert Delineated Boundaries. Urban Studies (Edinburgh, Scotland), 54(6), 1446-1462. https://doi.org/10.1177/0042098015620351

Kim, J., Jang, S., Kang, S., \& Kim, S. H. J. (2020). Why are hotel room prices different? exploring spatially varying relationships between room price and hotel attributes. Journal of Business Research, 107, 118-129. https://doi.org/10.1016/i.jbusres.2018.09.006

Leishman, C., Costello, G., Rowley, S., \& Watkins, C. (2013). The predictive performance of multilevel models of housing sub-markets: a comparative analysis, 50(May), 1201-1220. https://doi.org/10.1177/0042098012466603

Levkovich, O., Rouwendal, J., \& Brugman, L. (2018). Spatial planning and segmentation of the land market: The case of the Netherlands. Land Economics, 94(1), 137-154. https://doi.org/10.3368/le.94.1.137

Ling, C. S., Almeida, S., Shukri, M., \& Sze, L. Le. (2017). Imbalances in the property market.

Ling, Z., \& Hui, E. C. M. (2013). Structural change in housing submarkets in burgeoning real estate market: A case of Hangzhou, China. Habitat International, 39, 214-223. https:// doi.org/10.1016/i.habitatint.2012.12.006

Lipscomb, C. A., \& Farmer, M. C. (2005). Household diversity and market segmentation within a single neighborhood. The Annals of Regional Science, 39, 791-810. https://doi.org/10.1007/s00168005-0020-Z

Lisi, G. (2019). Property valuation: The hedonic pricing model - location and housing submarkets. Journal of Property Investment \& Finance, 37(6), 589-596. https:// doi.org/10.1108/JPIF-07-2019-0093

Manganelli, B., Pontrandolfi, P., Azzato, A., \& Murgante, B. (2014). Using geographically weighted regression for housing market segmentation Int. J. Business Intelligence And Data Mining, 9(2), 161-177. https://doi.org/10.1504/IJBIDM.2014.065100

Michaels, R. G., \& Smith, V. K. (1990). Market segmentation and valuing amenities hedonic models: The case of hazardous waste sites. Journal of Urban Economics, 28, 223-242. https://doi.org/10.1016/0094-1190(90)90052-O 
Mora-Garcia, R. T., Cespedes-Lopez, M. F., Perez-Sanchez, V. R., Marti, P., \& Perez-Sanchez, J. C. (2019). Determinants of the price of housing in the province of Alicante (Spain): Analysis using quantile regression. Sustainability (Basel), 11(2):437. https:// doi.org/10.3390/su11020437

Morano, P., Rosato, P., Tajani, F., Manganelli, B., \& Di Liddo, F. (2019). Contextualized property market models vs. generalized mass appraisals: An innovative approach. Sustainability (Basel), 11(18), 4896. https://doi.org/10.3390/su11184896

Nappi-Choulet Pr, I., \& Maury, T.-P. (2009). A spatiotemporal autoregressive price index for the Paris office property market. Real Estate Economics, 37(2), 305-340. https://doi.org/10.1111/j.1540$\underline{6229.2009 .00244 . x}$

Palm, R. (1978). Spatial segmentation of the urban housing market. Economic Geography, 54(3), $210-221$. https://doi.org/10.2307/142835

Pryce, G. (2013). Housing submarkets and the lattice of substitution. Urban Studies (Edinburgh, Scotland), 50(13), 2682-2699. Https://Doi.Org/10.1177/0042098013482502 https://doi.org/10.1177/0042098013482502

Raposo, I. G., \& Evangelista, R. (2017). A transactions-based commercial property price index for Portugal. Financial Stability Papers, 3(March), 1-25.

Rosen, S. (1974). Hedonic prices and implicit markets: Product differentiation in pure competition. Journal of Political Economy, 82(1), 34-55. https://doi.org/10.1086/260169

Roubi, S., \& Ghazaly, A. (2007). Pricing inter-neighbourhood variation: A case study on the rental apartment market in Greater Cairo. Property Management, 25(1), 68-79. https:// doi.org/10.1108/02637470710723263

Schnare, A. B., \& Struyk, R. J. (1976). Segmentation in urban housing markets. Journal of Urban Economics, 3(2), 146-166. https://doi.org/10.1016/0094-1190(76)90050-4

Seo, K. (2016). Impacts of transportation investment on real property values: an analysis with spatial hedonic price models. Proquest Dissertations And Theses, (April), 143. Retrieved From Http:/ /Search.Proquest.Com.Ezaccess.Library.Uitm.Edu.My/Docview/1793940515?Accountid=.

Seo, K., Salon, D., Kuby, M., \& Golub, A. (2019). Hedonic modeling of commercial property values: Distance decay from the links and nodes of rail and highway infrastructure. Transportation, 46(3), 859-882. Https:/ / Doi.Org/10.1007/S11116-018-9861-Z https:// doi.org/10.1007/s11116-018-9861-Z

Sevtsuk, A., \& Kalvo, R. (2018). Patronage of urban commercial clusters: A network-based extension of the huff model for balancing location and size. Environment and Planning. B, Urban Analytics and City Science, 45(3), 508-528. https://doi.org/10.1177/2399808317721930

Shi, D., Guan, J., Zurada, J., \& Levitan, A. S. (2015). An innovative clustering approach to market segmentation for improved price prediction. Journal Of International Technology And Information Management, 24(1), 15-32.

Sivitanidou, R. (1995). Urban spatial variation in office-commercial rent; the role of spatial amimities and commercial zoning. Journal of Urban Economics, 38, 23-49. https://doi.org/10.1006/juec.1995.1021

Soguel, N., Martin, M., \& Tangerini, A. (2008). The impact of housing market segmentation between tourists and residents on the hedonic price. Schweizerische Zeitschrift für Volkswirtschaft und Statistik, 144(4), 655-678.

Straszheim, M. (1975). An econometric analysis of the urban housing market. National Bureau Of Economic Research.,

Usman, H., Lizam, M., \& Adekunle, M. U. (2020). Property price modelling, market segmentation and submarket classifications: A review. Real Estate Management and Valuation, 28(3), 24-35. https://doi.org/10.1515/remav-2020-0021

Usman, H., \& Lizam, M. (2020). Empirical modelling of commercial property market location submarket using hedonic price model in Malaysia. Proceedings of the 5th NA International Conference on Industrial Engineering and Operations Management Detroit, Michigan, USA, August 10 - 14, 3396-3406.

Usman, H., Lizam, M., \& Burhan, B. (2020b). Review of issues in the conventional hedonic property pricing model. Proceedings of the 2nd African International Conference on Industrial Engineering and Operations Management Harare, Zimbabwe, December 7-10, 2806-2816.

Usman, H., Lizam, M., \& Burhan, B. (2020c). A review of property attributes influence in hedonic pricing model. Proceedings of the 2nd African International Conference on Industrial Engineering and Operations Management Harare, Zimbabwe, December 7-10, 2795-2805. 
Warren, C. M. J., Elliott, P., \& Staines, J. (2017). The impacts of historic districts on residential property land values in Australia. International Journal Of Housing Markets And Analysis, 10(1), 66-80. https://doi.org/10.1108/IJHMA-02-2016-0015

Watkins, C. (1999). Property valuation and the structure of urban housing markets. Journal of Property Investment \& Finance, 17(2), 157-175. https://doi.org/10.1108/14635789910258543

Wiley, J. A. (2017). Leverage, liquidity and information in commercial property prices. Journal of Property Research, 34(2), 77-107. https://doi.org/10.1080/09599916.2017.1320683

Wolverton, M., Hardin, W. G. III, \& Cheng, P. (1999). Disaggregation of local apartment markets by unit type. The Journal of Real Estate Finance and Economics, 19(3), 243-257. https://doi.org/10.1023/A:1007884628153

Xiao, Y., Webster, C., \& Orford, S. (2016). Can street segments indexed for accessibility form the basis for housing submarket delineation? Housing Studies, 31(7), 829-851. https://doi.org/10.1080/02673037.2016.1150433

Xu, T., Zhang, M., \& Aditjandra, P. T. (2016). The impact of urban rail transit on commercial property value: New evidence from Wuhan, China. Transportation Research Part A, Policy and Practice, 91, 223-235. https:// doi.org/10.1016/j.tra.2016.06.026

Yuan, F., Wei, D. Y., \& Wu, J. (2020). Amenity effects of urban facilities on housing prices in China: Accessibility, scarcity, and urban spaces. Cities (London, England), 96, 102433. https:// doi.org/10.1016/j.cities.2019.102433

Zhang, L., Zhou, J., \& Hui, E. C. (2020). Which types of shopping malls affect housing prices? from the perspective of spatial accessibility. Habitat International, 96(January), 102118. https:// doi.org/10.1016/j.habitatint.2020.102118

Zhuo Chen, Cho, S.-H., Poudyal, N., \& Roberts, R. K. (2009). Forecasting housing prices under different market segmentation assumptions. Urban Studies (Edinburgh, Scotland), 46(1), 167-187. https://doi.org/10.1177/0042098008098641 